\title{
PENGARUH KEPRIBADIAN, KECERDASAN EMOSIONAL, DAN PERILAKU KEWARGAAN ORGANISASI TERHADAP KINERJA KEPALA SEKOLAH MENENGAH ATAS DAN KEJURUAN DI KOTA TANGERANG
}

\section{Edi Riadi ${ }^{*}$}

\begin{abstract}
The Objective of the research is to obtain information about the effect of personality, emotional intelligence and organizational citizenship behavior on principal's performance of senior high school. The research was conducted to all of senior high schools principals in The City of Tangerang by using a survey method with path analysis applied in testing hypothesis. The number of 124 school Principal's as sample was selected by proportional random sampling. The research conclude: (1). there is direct effect of personality on principal's performance. (2). there is direct effect of emotional intelligence on principal's performance. (3). there is direct effect of organizational citizenship behavior on principal's performance. (4). there is direct effect of personality on principal's organizational citizenship behavior. (5). there is direct effect of emotional intelligence on principal's organizational citizenship behaviour. Therefore to enhance schools principal's performance can be carried out by personality, emotional intelligence, and the organizational citizenship behaviour.
\end{abstract}

Keywords: Personality, emotional intelligence, organizational citizenship behavior, principal's performance

\section{PENDAHULUAN}

Kepala sekolah sebagai agent of change perlu memahami peran pendidikan dalam konteks pembangunan bangsa sebagaimana Zamroni (2000:1) menyebutkan dua paradigma yang menjadi kiblat bagi pengambilan kebijakan dalam pengembangan kebijakan pendidikan yaitu paradigma fungsional dan paradigma sosialisasi. Paradigma fungsional melihat bahwa keterbelakangan dan kemiskinan dikarenakan masyarakat tidak memiliki sumber daya manusia yang memadai. Menurut pengalaman masyarakat di barat, lembaga pendidikan formal sistem persekolahan merupakan lembaga utama mengembangkan pengetahuan, melatih kemampuan dan keahlian dan menanamkan sikap modern para individu yang diperlukan dalam proses pembangunan sebagai human investmen. Sementara itu, paradigma sosialisasi melihat peranan pendidikan dalam pembangunan adalah: a) mengembangkan kompetensi individu, b) kompetensi yang lebih tinggi tersebut diperlukan untuk meningkatkan produktivitas dan c) secara umum, meningkatkan kemampuan warga masyarakat dan semakin banyaknya warga masyarakat yang memiliki kemampuan akan meningkatkan kehidupan masyarakat secara keseluruhan. Kepala sekolah juga perlu memahami wawasan bahwa dalam kontek pendidikan modern terdapat perubahan paradigma dari national boundaries ke International networking, dari state dependence ke public service, dari fragmented decision making ke International autonomy, sehingga paradigma global ini dapat dijadikan landasan filosofis dan pedoman mulai dari tingkat pemangku kebijakan sampai pada tingkat operasional atau unit pelaksana teknis di sekolah.

Jadi kepala sekolah merupakan agent of change dalam proses pendidikan. Kepala sekolah adalah orang yang paling bertanggungjawab dalam pencapaian mutu lulusan peserta didiknya. Meskipun fasilitas pendidikannya lengkap, namun bila tidak

\footnotetext{
* Dosen pada Fakultas Keguruan dan Ilmu Pendidikan Universitas Muhammadiyah Tangerang
} 
ditunjang oleh keberadaan kepala sekolah yang berkualitas, berkinerja tinggi, mustahil akan mendapatkan kompetensi lulusan yang maksimal. Oleh sebab itu kepala sekolah yang kompeten diduga merupakan faktor yang sangat menentukan tinggi rendahnya mutu pendidikan.

Unesco (2010:319) dalam laporan The International Commission on Education for Twenty-first Century, menyatakan bahwa kita tidak dapat mengharapkan kualitas pendidikan yang tinggi tanpa kepemimpinan kepala sekolah yang mampu kerjasama aktif dengan guru dalam manajemen sekolah. Para kepala sekolah dan guru membutuhkan pengetahuan dan keterampilan, karakter personal, prospek profesional, dan motivasi yang tepat jika ingin memenuhi ekspektasi stakeholder pendidikan. Penentu kualitas proses dan hasil pendidikan terletak pada kinerja kepala sekolah. Tanpa ada kinerja kepala sekolah yang kompeten dan profesional maka semua upaya untuk membenahi pendidikan diduga tidak akan efektif.

Namun kenyataannya di lapangan masih terdapat sejumlah fakta bahwa kepala sekolah diduga kurang memiliki kompetensi yang memadai. Berdasarkan hasil survey Departemen Pendidikan Nasional memperkirakan 70 persen dari 250 ribu kepala sekolah di Indonesia tidak kompeten. Berdasarkan ketentuan Direktorat Peningkatan Mutu Pendidik dan Tenaga Kependidikan Departemen Pendidikan Nasional, hampir semua kepala sekolah lemah di bidang kompetensi manajerial dan supervisi. Kesimpulan ini merupakan temuan Direktorat Peningkatan Mutu Pendidik dan Tenaga Kependidikan Departemen Pendidikan Nasional setelah melakukan uji kompetensi. Direktorat Peningkatan Mutu melakukan uji kompetensi berdasarkan Peraturan Menteri Pendidikan Nasional Nomor 13 Tahun 2007 tentang Kompetensi Kepala Sekolah. Lebih dari 400 kepala sekolah dari lima provinsi mengikuti tes tersebut. Untuk memastikan temuan itu, uji kompetensi kembali dilakukan terhadap 50 kepala sekolah, ternyata hasilnya hampir sama.

Di Kota Tangerang sendiri, dari 180 kepala sekolah SMA dan Kejuruan yang terdiri dari 15 kepala SMA Negeri, 72 kepala SMA swasta, 9 kepala SMK Negeri dan 76 kepala SMK Swasta serta 2 kepala MA dan 6 kepala MA swasta, berdasarkan hasil survey Tim MGMP Kota Tangerang tahun 2009, ternyata kondisinya juga tidak jauh berbeda yakni para kepala sekolah masih lemah dalam kompetensi kepribadian, sosial, kewirausahaan, dan kompetensi supervisinya.

Di samping itu juga terdapat sejumlah faktor yang diduga dapat mempengaruhi kinerja kepala sekolah diantaranya: kepribadian. Tett, Rothstein dan Jackson (1991:44) menemukan bahwa kestabilan emosi berkorelasi dengan kinerja, dan dua lainnya dari lima dimensi The Big five Personality yaitu agreeableness dan openness berkorelasi dengan kinerja lebih tinggi dari pada aspek conscientiousness.

Masalah kinerja diduga berkaitan dengan Kecerdasan emosional John J. Sosik dan Lara Megerian (1999:367) hasil kajian empirisnya memberikan dukungan untuk

kecerdasan emosional menjadi dasar dari aspek-aspek lain dari kepemimpinan. Demikian

halnya dengan penelitian Su Yung Fu (2000:45) "bahwa beberapa hasil penelitian mengindikasikan bahwa perilaku ekstra peran (extra role behavior) maupun kepuasan kerja secara keseluruhan memiliki hubungan dengan kinerja".

\section{Kinerja}

Secara umum Menurut Gibson et.al (1987:21), kinerja adalah tingkat keberhasilan dalam melaksanakan tugas dan kemampuan untuk mencapai tujuan yang telah 
ditetapkan. Batasan tersebut mengandung makna bahwa kinerja dinyatakan berhasil dan sukses, jika tujuan yang diinginkan dapat tercapai dengan baik. Pendapat senada juga dikemukakan oleh Brumbach dalam Michael Armstrong (2006:7) "performance means both behaviours and results. Behaviours emanate from the performer and transform performance from abstraction to action. Not just the instruments for results, behaviours are also outcomes in their own right - the product of mental and physical effort applied to tasks - and can be judged apart from results.

Untuk mengukur kriteria penilaian kinerja, Bernardin dan Russell (1983:383) mengungkapkan ada enam kriteria pokok yang dapat dipakai untuk mengukur kinerja, yaitu: 1). Quality. The degree to which the process or result of carrying out an activity approaches perfection, in term of either conforming to same ideal way of performing the activity or fulfilling the ac-tivity's intended purpose. 2). Quantity. The amount produced, expressed in such terms as dollar value, number of units, or completed activity cycles. 3). Timeliness. The degree to which an activity is completed, or a result produced, at the earliest time desirable from the standpoints of both coordinating with the outputs of others and maximizing the time available for other activities. 4). Cost effectiveness. The degree to which the use of the organi-zation's resources (e.g., human, monetary, technological, material) is maximized in the sense of getting the highest gain or reduction in loss from each unit or instance of use of resource. 5). Need for supervision. The degree to which a performer can carry out a job function without either having to request supervisory assistance or requiring supervisory intervention to prevent an adverse outcome. 6). Interpersonal impact. The degree to which a performer promotes feelings of self esteem, goodwill, and cooperation among coworkers and subordinates.

Dari uraian di atas, dapat disintesiskan kinerja adalah hasil kerja yang dicapai dalam melaksanakan tugas pokok, fungsi dan tanggung jawabnya untuk mencapai tujuan pendidikan yang dapat diukur dari beberapa aspek yaitu: Kompetensi manajerial, kompetensi supervisi, kompetensi kewirausahaan, dan kompetensi sosial.

\section{Kepribadian}

Kepribadian adalah salah satu faktor khas dan unik dari seseorang yang mendasari perilaku karyawan di tempat kerja. Menurut Gordon Allport dalam Robbins (2003:94) mengungkapkan bahwa, "personality is the dynamic organization within the individual of those psychophysical systems that determine his unique adjustments to the environment". Definisi yang paling populer ini mengandung makna bahwa kepribadian itu pada dasarnya merupakan satu kesatuan sistem fisik dan psikologis dalam diri individu yang menentukan penyesuaian uniknya terhadap lingkungan. Hal senada dikemukakan oleh Slocum Hellriegel (2009:36) bahwa, "personality represent the overall profile or combination of stable

psychological attributes that capture the unique nature of person. Therefore, personality combines a set of physical and mental characteristic that reflect how person a look, thinks, acts, and feels. This definition contains two important ideas". Menurut Slocum Hellriegel menjelaskan bahwa teori kepribadian selalu menggambarkan apa yang sudah menjadi kebiasaannya dengan orang lain dan apa yang sudah membentuknya dalam waktu tertentu. Untuk memahami apa yang sudah menjadi kebiasaan individu dan yang membuat keunikan individu, maka setiap pekerja di dalam sebuah organisasi adalah khas, mungkin bisa sama atau tidak sama pada situasi yang sama. Karakteristik kepribadian merupakan salah satu aspek penting dalam kematangan karir dan kinerja seseorang dalam menjalani kehidupan karirnya. Dengan mengenal tipe kepribadiannya individu 
mendapatkan arah mengenai bidang karir/pekerjaan/jabatan yang sesuai untuk dipilih dan dikembangkan dalam perjalanan hidupnya.

Beberapa faktor umum yang telah diidentifikasi oleh para ahli dalam menggambarkan kepribadian terangkum dalam alat ukur yang populer digunakan diantaranya, "the Big Five Personality Factor, Minnesota Multiphasic Personality Inventory (MMPI), Myers-Briggs Type Indicator (MBTI), CPI (California Psychological Inventory), Guilford-Zimmerman Temperament Survey, Sixteen Perso-nality Questionnaire (16 PF), TAT (Thematic Apperseption Test), EPPS (Edwards Per-sonal Preference Schedule), Tes Rorschach (Tes Ro), Draw A Man (DAM) dan secara tipikal untuk mendapatkan sebuah perspektif dari kepribadian dapat juga diukur melalui berbagai aspek kepribadian seperti Locus of control, creativity, atau Machiavellianism" dan lain sebagainya.

Mengingat luasnya dimensi-dimensi kepribadian individu dan beragamnya metode pengukuran kepribadian seperti tersebut di atas, maka dalam penelitian ini akan difokuskan pada lima besar dimensi kepribadian lazim disebut "The Big Five Personality Factor" yang diadaptasi dari International Personality Item Pool (IPIP). Menurut Golgberg (1992:55) dalam International Personality Item Pool (IPIP), "The Big Five" kepribadian terdiri dari lima faktor sebagai berikut, " the five factors have traditionally been numbered and labeled as follows: I.Surgency (or Extraversion); II. Agreeableness; III. Conscientiousness (or Dependability); IV Emotional Stability (vs. Neuroticism); and V Culture, Intellect, or Openness". Sedangkan menurut Colquitt, Le Pine dan Wesson (2009:298) lima dimensi dari kepribadian dapat digambarkan sebagai berikut: 1). Agreeableness adalah orangorang yang memiliki kehangatan, kebaikan, kooperatif, simpatik, penolong dan sopan. 2). Extraversion adalah orang yang banyak bicara, ramah, bersemangat, tegas, berani, dan dominan (berbeda dengan introvert, yang agak, pemalu, dan pendiam). 3). Neuroticism adalah orang neurotik yang gugup, murung, emosional, tidak nyaman, dan cemburu. 4). Emotional Stability" atau "Emotional Adjustment". 5).Openness to experience adalah orangorang terbuka selalu ingin tahu, imajinatif, kreatif, halus, dan moderat.

Berdasarkan uraian di atas, dapat disintesiskan bahwa kepribadian adalah satu kesatuan sistem fisik dan psikologis yang komplek dan dinamis dalam diri individu tentang bagaimana individu melihat, berpikir, bertindak, dan beradaptasi dengan lingkungannya sehingga akan tampak dalam tingkah lakunya yang unik dan berbeda dengan orang lain.

\section{Kecerdasan Emosional}

Menurut Daniel Goleman dalam Kinicky dan Kreitner (2008:131) memberikan batasan bahwa kecerdasan emosional adalah kemampuan untuk mengelola diri sendiri dan hubungan seseorang dengan cara yang dewasa dan konstruktif. Oleh sebagian orang sering disebut EI dan lainnya menyebut EQ, kecerdasan emosional memiliki empat dimensi yaitu self awareness, self management, social awareness, dan relationship management. Dua yang pertama merupakan kompetensi pribadi, dan yang dua lainnya kompetensi sosial. Robbins dan Judge (2007:248) secara garis besar memaparkan batasan kecerdasan emosional sebagai berikut, "emotional Intelligence (EI) is one ability to detect and to manage emo-tional cues and informational, often overreacts to problems and chooses the most ineffectual responses to emotional situations, So, people who know their own emotions and are good at reading other's emotions may be more effective in their jobs". Kecerdasan emosi merupakan salah satu kemampuan untuk mendeteksi dan untuk mengelola isyarat emosional dan informasi, sering menangani masalah dan memilih jawaban dengan 
tidak emosi. Jadi, orang yang tahu emosi mereka sendiri dan pandai membaca emosi orang lain mungkin lebih efektif dalam pekerjaannya. Secara singkat Robbins (2007:248) menjelaskan bahwa kecerdasan emosional terdiri dari lima dimensi sebagai berikut, "emotional Intelligence is composed of five dimensions: Self-awareness: being aware of what you're feeling Self-management: the ability to manage your own emotional and impulse. Selfmotivation: the ability to persist in the face of setbacks and failrules. Empathy: the ability to sense how others are feeling Social skills: the ability to handle the emotions of others".

Sedangkan Daniel Goleman seperti yang dikutip oleh Fred Luthan (2008:88) secara lebih terperinci menjelaskan bahwa karakteristik kecerdasan emosional menjadi 5 dimensi yaitu: 1). self awareness adalah pemahaman diri, pengetahuan tentang perasaan yang sebenarnya pada saat ini. 2). self management adalah kemampuan menangani emosi untuk memfasilitasi bukan menghalangi; dan melepaskan emosi negatif kemudian kembali ke jalur yang konstruktif untuk pemecahan masalah. 3). self motivation adalah keteguhan dalam menuju tujuan yang diinginkan; mengatasi dorongan emosi negatif dan menunda kepuasan untuk mencapai hasil yang diinginkan. 4). empathy adalah Memahami dan peka terhadap perasaan orang lain; mampu merasakan apa yang orang lain rasakan dan inginkan. 5). social skill adalah kemampuan untuk membaca situasi sosial; luwes dalam berinteraksi dengan orang lain; serta mampu mengarahkan emosi orang lain dan cara, tindakannya.

Dari uraian di atas, dapat disintesiskan bahwa kecerdasan emosional adalah kemampuan yang dimiliki seseorang dalam mengenali, mengelola dan mengendalikan emosi diri sendiri, memahami perasaan orang lain, menjalin hubungan baik dengan orang lain dengan cara dewasa dan konstruktif dalam situasi sosial.

\section{Perilaku Kewargaan Organisasi (Organizational Citizenship Behavior)}

Organizational Citizenship Behavior (OCB) merupakan kontribusi individu yang mendalam melebihi tuntutan peran di tempat kerja dan direward oleh perolehan kinerja. Hal ini sependapat dengan batasan Kinicky dan Kreitner (2008:165) mengenai OCBs yang menjelaskan, "organizational citizenship behaviors (OCBs) consist of employee behaviors that are behaviors (OCBs) beyond the call of duty. Examples include "such

gestures as construetive statements about the department, expression of personal interest in the work of others, suggestions for improvement training new people, respect for the spirit as well as the letter of house keeping rules, care for organizational property, and punctually and attendance well beyond standard or enforceable levels. Managers certainly would like employees to exhibit these behaviors"'".

Perilaku kewargaan organisasi terdiri dari perilaku karyawan di luar panggilan tugas. Contoh ini termasuk sikap seperti ungkapan konstruktif tentang organisasi, ekspresi kepedulian terhadap pekerjaan orang lain, saran untuk perbaikan pelatihan terhadap karyawan baru, menghormati semangat serta patuh dalam menjaga aturan organisasi, merawat properti organisasi, tepat waktu dan kehadiran jauh melampaui tingkat standar atau ditegakkan. Manajer pasti akan menyukai karyawan untuk menunjukkan perilaku seperti itu. Menurut Organ dalam Fred Luthan (2008:149) memaparkan perilaku kewargaan organisasi memiliki karakteristik sebagai berikut, "organ defines OCB as "individual behavior that is discretionary, not directly or explicitly recognized by the formal reward system, and that in the aggregate promotes that effective functioning of the organization". The personality foundation for these OCBs reflects the employee's predispositional traits to be cooperative, helpful, 
caring and conscientious. The attitudinal foundation indicates that employees engage in OCBs in order to reciprocate the actions of their organizations.Motivational dimensions, job satisfactions, and organizational commitment clearly relate to OCBs. More important to OCBs, however, is that employees must perceive that they are being treated fairly, that the procedures and outcomes are fair. A number of studies have found a strong relationship between justice and OCBs. It seems that procedural justice affects employees by influencing their perceived organizational support, which in turn prompts them to reciprocate with OCBs, going beyond the formal job requirements". Organ mendefinisikan perilaku kewargaan organisasi sebagai perilaku individu yang mempunyai atau menggunakan kemampuan untuk bertindak atau memutuskan sesuai dengan kebijaksanaannya sendiri, tidak secara langsung atau secara eksplisit diakui oleh sistem reward formal, dan sebagai fungsi efektif organisasi dalam mempromosikan karyawan. Landasan kepribadian untuk perilaku kewargaan organisasi ini mencerminkan sifat predispositional karyawan untuk bersikap kooperatif, membantu, peduli dan teliti. Landasan sikap menunjukkan bahwa karyawan terlibat dalam perilaku kewargaan organisasi dalam rangka membalas tindakan organisasinya. Dimensi motivasi, kepuasan kerja, dan komitmen organisasi jelas berhubungan dengan perilaku kewargaan organisasi. Yang lebih penting untuk Perilaku Kewargaan Organisasi, bagaimanapun, adalah bahwa karyawan harus merasa bahwa mereka sedang diperlakukan adil secara prosedural. Sejumlah penelitian telah menemukan hubungan yang kuat antara keadilan dan Perilaku Kewargaan Organisasi. Tampaknya bahwa keadilan prosedural mempengaruhi karyawan dengan mempengaruhi dukungan dirasakan organisasi mereka, yang pada gilirannya mendorong mereka untuk membalas dengan Perilaku Kewargaan Organisasi, melampaui persyaratan kerja formal.

Berdasarkan uraian di atas, dapat disintesiskan bahwa perilaku kewargaan organisasi adalah perilaku individu yang mencerminkan warga organisasi yang baik, sadar akan hak dan kewajibannya terhadap organisasi, membela dan menjaga martabat organisasi tanpa pamrih, patuh dan taat dalam menjaga aturan organisasi, merawat properti organisasi serta berperilaku melampaui tingkat standar yang ditegakkan.

\section{METODE}

Tempat dan objek penelitian adalah seluruh Sekolah Menengah Atas dan Kejuruan di Kota Tangerang, dengan populasi seluruh Kepala SMA/K Kota Tangerang. Sampel yang digunakan adalah Stratified Random Sampling dengan jumlah 124 Kepala Sekolah. Metode yang digunakan dalam penelitian ini adalah metode survey dengan menggunakan kuesioner sebagai alat pengumpulan data pokok, yang dapat digunakan untuk menjelaskan hubungan kausal dan pengujian hipotesis pada fenomena sosial yang sudah berlangsung pada masa sekarang (ex post facto) dimana peneliti tidak memberikan pengaruh ataupun kondisi apapun terhadap subyek penelitian. Penelitian dilaksanakan setelah perbaikan seminar proposal sampai dengan seminar hasil pada tahun 2011.

Penelitian ini menggunakan analisis jalur untuk mengetahui adanya pengaruh antar variabel sesuai dengan model kausal yang terbentuk. Sebelum kuesioner digunakan dalam penelitian ini terlebih dahulu dilakukan uji coba untuk menentukan validitas dan reliabilitas instrumen. Hasil tersebut digunakan sebagai instrumen untuk mengambil data penelitian di lapangan. Analisis data meliputi: 1). deskripsi data, 2). uji prasyarat analisis normalitas, uji regresi dan uji korekasi. 3). analisis jalur yang meliputi: analisis model, pengujian hipotesis dan penentuan tingkat pengaruh. 


\section{HASIL DAN PEMBAHASAN}

Hipotesis pertama: Terdapat pengaruh langsung positif kepribadian $\left(X_{1}\right)$ terhadap kinerja kepala SMA di Kota Tangerang $\left(\mathrm{X}_{4}\right)$

Hipotesis pertama: Terdapat pengaruh langsung positif kepribadian $\left(X_{1}\right)$ terhadap kinerja kepala SMA di Kota Tangerang $\left(\mathrm{X}_{4}\right)$. Dari hasil perhitungan diperoleh nilai koefisien jalur $\mathrm{p}_{41}=0.147$ dengan nilai $\mathrm{t}_{\text {-hitung }}=1,93$. Nilai pada $\mathrm{t}$ tabel dengan tingkat signifikansi 0,05 dan jumlah responden $(n)=124$ diperoleh angka $t_{\text {tabel }}=1,66$. Berdasarkan nilai estimasi koefisien jalur dan nilai thitung pengaruh langsung kepribadian terhadap kinerja kepala sekolah meskipun tidak terlalu tinggi sebesar 0,143 namun tetap signifikan terbukti de ngan thitung $=1,93>t_{-t a b e l}=1,66$, dengan demikian hipotesis 1 yang menduga terdapat pengaruh langsung kepribadian terhadap perilaku kewargaan organisasi kepala sekolah dapat diterima. Hal ini mencerminkan bahwa semakin positif kepribadian kepala sekolah maka semakin tinggi perilaku kewargaan organisasinya.

Hipotesis kedua: Terdapat pengaruh langsung positif kecerdasan emosioanal $\left(\mathrm{X}_{2}\right)$ terhadap kinerja kepala SMA di Kota Tangerang $\left(\mathrm{X}_{\mathbf{4}}\right)$

Dari hasil perhitungan diperoleh nilai koefisien jalur $\mathrm{p}_{41}=0.21$ dengan nilai $\mathrm{t}^{\mathrm{t}}$ hitung $=$ 2,76. Sedangkan Nilai pada $\mathrm{t}$ tabel dengan tingkat signifikansi 0,05 dan jumlah responden $(n)=124$ diperoleh angka $t_{\text {tabel }}=1,66$. Berdasarkan nilai estimasi koefisien jalur dan nilai thitung pengaruh langsung kecerdasan emosional terhadap kinerja kepala sekolah meskipun tidak terlalu tinggi yakni sebesar 0,21 namun tetap signifikan, terbukti dengan thitung $=2,76>\mathrm{t}$-tabel $=1,66$, dengan demikian hipotesis 2 yang menduga terdapat pengaruh langsung kecerdasan emosional terhadap kinerja kepala sekolah dapat diterima. Hal ini sekaligus mencerminkan bahwa semakin tinggi kecerdasan emosional kepala sekolah maka semakin tinggi kinerjanya.

Hipotesis ketiga: Terdapat pengaruh langsung positif perilaku kewargaan organisasi $\left(\mathrm{X}_{3}\right)$ terhadap kinerja kepala SMA di Kota Tangerang $\left(\mathrm{X}_{4}\right)$

Dari hasil perhitungan diperoleh nilai koefisien jalur $\mathrm{p}_{43}=0.50$ dengan nilai $\mathrm{t}$-hitung $=$ 6,58 . Sedangkan nilai pada $t$ tabel dengan tingkat signifikansi 0,05 dan jumlah responden 124 diperoleh angka $t_{\text {tabel }}=1,66$. Berdasarkan nilai estimasi koefisien jalur dan nilai thitung pengaruh langsung kepribadian terhadap kinerja kepala sekolah cukup tinggi yakni sebesar 0,50 sehingga koefisien jalurnya cukup signifikan terbukti de ngan thitung $=6,58>\mathrm{t}^{-}$tabel $=1,66$, dengan demikian hipotesis 3 yang menduga terdapat pengaruh langsung perilaku kewargaan organisasi terhadap kinerja kepala sekolah dapat diterima. Hal ini sekaligus mencerminkan bahwa semakin tinggi perialku kewargaan organisasi kepala sekolah maka semakin tinggi kinerjanya.

Hipotesis keempat: Pengaruh langsung positif kepribadian $\left(X_{1}\right)$ terhadap perilaku kewargaan organi-sasi kepala SMA di Kota Tangerang $\left(X_{3}\right)$ 
Dari hasil perhitungan diperoleh nilai koefisien jalur $\mathrm{p}_{31}=0.254$ dengan nilai t-hitung $=3,18$. Nilai pada $t$ tabel dengan tingkat signifikansi 0,05 dan jumlah responden $(n)=$ 124 diperoleh angka $t_{\text {tabel }}=1,66$. Berdasarkan nilai estimasi koefisien jalur dan nilai thitung pengaruh langsung kepribadian terhadap perilaku kewargaan organisasi kepala sekolah meskipun tidak terlalu tinggi sebesar 0,254 namun tetap signifikan terbukti dengan thitung $=3,18>\mathrm{t}_{\text {-tabel }}=1,66$, dengan demikian hipotesis 4 yang menduga terdapat pengaruh langsung kepribadian terhadap perilaku kewargaan organisasi kepala sekolah dapat diterima. Hal ini mencerminkan bahwa semakin positif kepribadian kepala sekolah maka semakin tinggi perilaku kewargaan organisasinya.

\section{Hipotesis kelima: Terdapat pengaruh langsung positif kecerdasan emosional $\left(\mathrm{X}_{2}\right)$ terhadap perilaku kewargaan organisasi kepala SMA di Kota Tangerang $\left(X_{3}\right)$}

Dari hasil perhitungan diperoleh nilai koefisien jalur $\mathrm{p}_{32}=0.52$ dengan nilai $\mathrm{t}$-hitung $=$ 6.51 Nilai pada $t$ tabel dengan tingkat signifikansi 0,05 dan jumlah responden $(n)=124$ diperoleh angka $t_{\text {tabel }}=1,66$. Berdasarkan nilai estimasi koefisien jalur dan nilai thitung pengaruh langsung kepribadian terhadap perilaku kewargaan organisasi kepala sekolah cukup tinggi sebesar 0,52 jadi cukup signifikan terbukti dengan thitung $=6.51$ $>{ }^{t}$-tabel $=1,66$, dengan demikian hipotesis 5 yang menduga terdapat pengaruh langsung kecerdasan

emosional terhadap perilaku kewargaan organisasi kepala sekolah dapat diterima. Hal ini mencerminkan bahwa semakin tingggi kecerdasan emosional kepala sekolah maka semakin tinggi perilaku kewargaan organisasinya.

\section{Pengaruh tidak langsung positif kepribadian $\left(X_{1}\right)$ terhadap kinerja kepala sekolah $\left(\mathrm{X}_{4}\right)$}

\section{melalui perilaku kewargaan organisasi $\left(\mathrm{X}_{3}\right)$}

Berdasarkan nilai estimasi koefisien jalur dan nilai thitung pengaruh tidak langsung kepribadian terhadap kinerja kepala sekolah melalui perilaku kewargaan organisasi cukup signifikan yakni sebesar 0,125. Hal ini sekaligus mencerminkan bahwa semakin tinggi kepribadian kepala sekolah maka semakin tinggi kinerjanya melalui perilaku kewargaan organisasi.

\section{Pengaruh tidak langsung positif kecerdasan emosional $\left(X_{2}\right)$ terhadap kinerja kepalah sekolah $\left(X_{4}\right)$ melalui perilaku kewargaan organisasi $\left(X_{3}\right)$}

Berdasarkan nilai estimasi koefisien jalur dan nilai thitung pengaruh tidak langsung kecerdasan emosional terhadap kinerja kepala sekolah melalui perilaku kewargaan organisasi cukup signifikan yakni sebesar 0,260 . Hal ini sekaligus mencerminkan bahwa semakin tinggi kecerdasan emosional kepala sekolah maka semakin tinggi kinerjanya melalui perilaku kewargaan organisasi. Secara lengkap dapat digambarkan diagram jalur empiris hubungan kausal antar variabel penelitian.

\section{PENUTUP}


Kesimpulan. Berdasarkan hasil analisis data, maka dapat disampaikan kesimpulan sebagai berikut: (1) Terdapat pengaruh langsung positif kepribadian terhadap kinerja kepala sekolah. Artinya jika dimensi kepribadian kepala sekolah makin terbuka, ramah, intelektualitasnya tinggi dan emosionalnya stabil maka kinerja kepala sekolah akan meningkat. (2) Terdapat pengaruh langsung positif kecerdasan emosional terhadap kinerja kepala sekolah. Artinya bahwa jika dimensi kecerdasan emosional kepala sekolah makin peka, empatinya tinggi, fleksibel dan memiliki keterampilan sosial maka kinerja kepala sekolah akan meningkat. (3) Terdapat pengaruh langsung positif perilaku kewargaan organisasi terhadap kinerja kepala. Artinya bahwa jika dimensi perilaku kewargaan organisasi kepala sekolah makin patuh dan taat pada peraturan, suka menolong, antisipatif, relawan, dan sportif, maka kinerja kepala sekolah akan meningkat. (4) Terdapat pengaruh langsung positif kepribadian terhadap perilaku kewargaan organisasi kepala sekolah. Artinya jika dimensi kepribadian kepala sekolah makin terbuka, ramah, intelektualitasnya tinggi, dan emosionalnya stabil maka perilaku kewargaan organisasinya akan meningkat. (5) Terdapat pengaruh langsung positif kecerdasan emosinal terhadap perilaku kewargaan organisasi kepala sekolah. Artinya bahwa jika dimensi kecerdasan emosional kepala sekolah makin peka, empatinya tinggi, fleksibel dan memiliki keterampilan sosial maka perilaku kewargaan organisasinya akan meningkat. (6) Kepribadian berpengaruh tidak langsung ter hadap kinerja kepala sekolah melalui perilaku kewargaan organisasi. Artinya jika dimensi kepribadian kepala sekolah makin terbuka, ramah, intelektualitasnya tinggi dan emosionalnya stabil maka kinerja kepala sekolah akan meningkat melalui perilaku kewargaan organisasi. (7) Kecerdasan emosional berpengaruh tidak langsung terhadap kinerja kepala sekolah melalui perilaku kewargaan organisasi. Artinya jika dimensi kecerdasan emosional kepala sekolah makin peka, empatinya tinggi, fleksibel dan memiliki keterampilan sosial maka kinerja kepala sekolah akan meningkat melalui perilaku kewargaan organisasi.

Saran. Berdasarkan Saran yang terkait dengan penelitian ini mencakup: Kepada kepala sekolah. Kinerja hendaknya jangan hanya dipersepsikan sederhana sebagai mobilisasi segala sumber daya pendidikan untuk mencapai tujuan belaka, akan tetapi kinerja seyogyanya harus dipandang sebagai fungsi untuk memberi informasi bagi dirinya dan atasannya mengenai bagaimana seseorang telah melakukan pekerjaan, kinerja sebagai fungsi interaksi antara kemampuan, karakter pribadi (personality and emotion), dengan fungsi-fungsi manajemen. Oleh karena itu untuk meningkatkan kinerja, kepala sekolah hendaknya memahami kinerja sebagai fungsi interaksi antara kemampuan manajerial dengan karakter personal, kecerdasan emosional dan berupaya untuk selalu meningkatkan perilaku kewargaan organisasinya. Kepada Kepala Dinas Pendidikan. Kepala dinas pendidikan hendaknya mengkaji ulang dalam pelaksanaan rekrutmen, seleksi dan pengangkatan kepala sekolah tidak hanya melihat dari aspek senioritas atau jenjang pangkat dan golongan saja tetapi juga memperhatikan aspek individual's attribute managerial action, individual work effort, individual work motivation dan individual work performance yang dimiliki oleh calon kepala sekolah yang akan dipromosikan. Bagi pengawas pembina sekolah. Dengan adanya temuan-temuan dalam penelitian ini maka diharapkan agar dapat dijadikan bahan pertimbangan bagi para pengawas untuk mengadakan perbaikan dan pengembangan kinerja kepala sekolah melalui kepribadian, meningkatkan kecerdasan emosional dan perilaku kewargaan organisasi dalam konteks peningkatan kinerja kepala sekolah. 


\section{DAFTAR RUJUKAN}

Bernardin, H. John \& Joyce E. A. Russell, Human Resource Management. Singapore : McGraw Hill Inc, 1993.

Colquitt, Le Pine, Wesson, Organizational Behavior. New York USA: McGraw Hill, 2009.

Gibson, Ivancevich, Donnelly, Konopaske, Organizational Behavior: Structure Process. New York: Mc Graw Hill, 2006.

Gibson, Ivancevich, Donnelly, Ordanisasi: Perilaku-Struktur-Poses. Jakarta: Erlangga, 1987.

Kinicki \& Kreitner, Organizational Behavior: Key Concept, Skill and best Practices. New York: Mc Graw Hill Irwin, 2008.

Luthans, Fred. Organizational Behavior. New York USA Mc Graw Hill 11 ${ }^{\text {th }}$ Edition, 2008.

Rothstein, H. R, "Interrater reliability of job performance: Growth to asymptote level with increasing opportunity to observe", Journal of Psychology, vol.75, 22 Jun 2006.

Slocum, Hellriegel, Principles of Oraganizational Behavior $12^{\text {th }}$ Edition, South-Western Chengage Learning, International Student. 2009.

SP Robbins, Organizational Behavior, 7th Edition. New Jersey USA: Prentice Hall, 2003.

Stepen Robbins \& TA Judge, Organizational Behavior, $12^{\text {th }}$ Edition. NY: Pearson Int, 2007.

Su-Yung "The Relationship among Transformational Leadership, Organizational Commitment and Citizenship Behavior: The Case of Expatriates". (disertasi.umm. ac.id/...jiptummpp-gdl-jou-2009-thomasstef-16947-kepemimp-n.pdf) (diunduh 6 Nopember 2010).

Zamroni, Paradigma Pendidikan Masa Depan. Yogyakarta: Bigraf, 2000. 